\title{
Investigation of Bacillus pumilus and Staphylococcus haemolyticus adhesion on 304L Stainless Steel in Atmospheric Simulated Medium
}

\author{
Amal El Aabedy, \\ Saad Koraichi Ibnsouda, \\ Omar El Farricha, \\ Laboratory of Microbial Biotechnology, Faculty of Sciences and \\ Technology, University Sidi Mohamed Ben Abdellah, Fez, Morocco
}

Doi: 10.19044/esj.2019.v15n18p1 ～URL:http://dx.doi.org/10.19044/esj.2019.v15n18p1

\begin{abstract}
The bacteria adhesion on materials surface is the first step to formation of biofilm that could lead to biocorrosion. This study aimed to investigate the correlation between bacteria adhesion and the physicochemical properties of both materials and bacteria in atmospheric simulated medium. The material used in this study is 304L stainless steel and Bacillus pumilus and Staphylococcus haemolyticus bacteria strains. The hydrophobicity, electron donor and electron receptor properties were determined by contact angle measurements. In addition, the bacteria capacity of adhesion was followed by using a scanning electron microscope. The contact angle measurements finding showed that both bacteria have hydrophilic surfaces qualitatively and qualitatively. Otherwise, the stainless steel has revealed a hydrophobic character qualitatively and quantitatively. Moreover, the scanning electron microscope displayed the high speed of adhesion of the studied bacteria. The contact angle measurements could be used as a mean to prevent biocorrosion caused by bacteria adhesion.
\end{abstract}

Keywords: Adhesion, stainless steel, atmospheric simulated medium, biocorrosion

\section{Introduction}

Microbiologically Influenced Corrosion (MIC) or biocorrosion is an electrochemical phenomenon in which microorganisms adhere to the surfaces of metals or other materials. This adhesion can induce or accelerate corrosion reactions of these materials through the interfacial interaction with the metabolic activities of these microorganisms (Javaherdashti, 2016). This process of biocorrosion could be able to initiate, facilitate or accelerate 
corrosion reactions through the interaction of the three components: metal, solution and micro-organisms (De Romero et al., 2004).

It is, in fact, interactions between the living world and materials via adhesion; any material in contact with a biologically active medium is likely to be a victim of biocorrosion. Actually, the microorganisms don't "nibble" the material, but they change, drastically, due to their metabolism, the physical chemistry environment of the material interface $(\mathrm{pH}$, oxygen concentration, chemical concentration, ...) creating the conditions triggering the biocorrosion (Videla, 2002; Videla \& Herrera, 2004) . Microorganisms can be considered as great catalysts of the phenomenon of electrochemical nature: corrosion.

The adhesion of microorganisms to surfaces is the first step in biofilm formation (Queiroz et al., 2018). It depends on the interaction energy between the surface in the presence of microorganisms, and the surrounding environment (Katsikogianni \& Missirlis, 2004). Thus, many parameters may alter these interactions can potentially influence microbial adhesion to a solid support.

Therefore, the use of the contact angle goniometer, which is an analysis method of surfaces, has been implemented in order to describe the physicochemical properties of microorganisms surface (Sadiki et al., 2017) (Bacillus pumilus and Staphylococcus haemolyticus in this case, which were isolated from a 304L stainless steel plate) in term of hydrophobicity and electron acceptor / donor properties.

Subsequently, it was interesting to evaluate the adhesive behavior of these microorganisms on the surface of the 304L stainless steel using the Environmental Scanning Electron Microscopy (ESEM).

Most of biocorrosion studies have conducted their researches in acidic medium (Agarry et al., 2018) or seawater simulated medium (Rasheed et al., 2018) or cooling tower water solution (Narenkumar et al., 2019), that why this research has the privilege to be the first one that uses a simulated atmospheric medium to study the bacteria adhesion on a metallic surface.

The aim of this work was to investigate the correlation between adhesion and the physicochemical properties of 304L stainless steel surface and bacteria surface (Bacillus pumilus and Staphylococcus haemolyticus) in atmospheric simulated medium.

\section{Materials and Methods}

\section{1) Bacteria isolation, growth conditions and identification}

Bacillus pumilus and Staphylococcus haemolyticus were isolated from a 304L stainless steel plate using moist sterile cotton-tipped swabs. The swabs are then used to transfer bacteria to petri dishes filled with Lysogeny broth (LB) agar medium $\left(5 \mathrm{~g} \mathrm{~L}^{-1}\right.$ yeast extract, $10 \mathrm{~g} \mathrm{~L}^{-1}$ Tryptone, $10 \mathrm{~g} \mathrm{~L}^{-1} \mathrm{NaCl}, 20 \mathrm{~g}$ 
$\mathrm{L}^{-1}$ agar) prepared with atmospheric simulated water, which were incubated in $37^{\circ} \mathrm{C}$ for 24 hours.

Succeeding the work of Rocca et al. (2004), the international standard ASTM D1384 solution was used to simulate atmospheric corrosion (148 mg $\mathrm{L}^{-1} \mathrm{Na}_{2} \mathrm{SO}_{4}, 138 \mathrm{mg} \mathrm{L}^{-1} \mathrm{NaHCO}_{3}$ and $\left.165 \mathrm{mg} \mathrm{L}^{-1} \mathrm{NaCl}\right)$. The molecular identification of the strains is conducted by PCR-sequencing process. This method consists in carrying out a succession of replication reactions of double stranded DNA template. After extracting the genomic DNA of the various isolates, amplification of the $16 \mathrm{~S}$ rDNA for bacteria by PCR was performed. Primers that were used are universal primers: FD1 and RS16 primers were used to identify bacteria (Mostakim et al., 2011). The resulting PCR product was sequenced by the automated technique of Sanger using the ABI 3130 (Applied Biosystems, France) sequencing machine. Finely, the BLAST (Basic Local Alignment Search) data base tool was used for sequences identification.

\section{2) Substrate preparation}

The stainless steel specimens were purchased from Sonasid Company (Nador-Morocoo). The nominal elemental composition (wt \%) of the 304L sample was: Fe $71.376 \%, \mathrm{Ni} 8.18 \%, \mathrm{C} 0.053 \%, \mathrm{Cr} 18.08 \%, \mathrm{Cu} 0.06 \%, \mathrm{Mn}$ $1.68 \%$, Mo $0.05 \%$, N $0.047 \%$, P $0.037 \%$, S $0.007 \%$, and Si 0.43\%. Rectangleshaped specimens with dimensions of $10 \mathrm{~mm}$ x $25 \mathrm{~mm}$ and thickness of $3 \mathrm{~mm}$ were used for SEM and contact angle analysis. The specimens were cut from the original plate samples with the dimension of $100 \times 100 \times 3 \mathrm{~mm}$. Prior to the experiments, each specimen was sequentially ground with a series of emery papers (of 180, 600, 800, and 1200 grade) to a smooth surface, rinsed with sterile deionized water thrice, degreased in acetone, followed by sterilizing in $70 \%$ ethanol for $8 \mathrm{~h}$, and then dried aseptically in a laminar flow cabinet. The newly prepared specimens were immediately immersed in the test medium for all of the experiments.

\section{3) Determination of the physicochemical properties of bacteria and stainless steel surfaces - Contact angle measurements}

Physicochemical properties of the microbial cell and stainless steel surfaces were determined using a goniometer apparatus by the sessile drop method (Hassan et al., 2014; Barkai et al., 2015; Chen 2015). The bacteria was suspended in $\mathrm{KNO}_{3}(0.1 \mathrm{M})$ sterile solution, followed by centrifugation at $10.000 \mathrm{~g}$ for $15 \mathrm{~min}$. The pellet was then washed twice with sterile $\mathrm{KNO}_{3}$ and re-suspended in the same solution at a concentration of $10^{8} \mathrm{CFU} / \mathrm{ml}$. were filtered throughout a cellulose acetate membrane filter $(0.45 \mu \mathrm{m})$ by using a negative pressure system. For each strain, three independently grown cultures were used, from which three filters of each were prepared and measured. For the determination of interfacial free energy of the solid surface (bacteria and 
stainless steel), three liquids are recommended (Van Oss, 1993). They consist of two polar liquids (Water and Formamide) and one apolar liquid (Diiodomethane) with known surface tension characteristics (Table 1). The initial contact angle of each liquid was measured after drop stabilization on the solid sample surfaces. Three measurements of contact angles were made on each surface of substrate for all probes.

Table 1: Surface energy properties of pure liquid used to measure contact angles

\begin{tabular}{lccc}
\hline \multicolumn{1}{c}{ Liquid } & $\gamma^{\mathrm{LW}}\left(\mathrm{mJ} / \mathrm{m}^{2}\right)$ & $\gamma^{+}\left(\mathrm{mJ} / \mathrm{m}^{2}\right)$ & $\gamma^{-}\left(\mathrm{mJ} / \mathrm{m}^{2}\right)$ \\
\hline Water $\left(\mathrm{H}_{2} \mathrm{O}\right)$ & 21.8 & 25.5 & 25.5 \\
Formamide $\left(\mathrm{CH}_{3} \mathrm{NO}\right)$ & 39 & 2.3 & 39.6 \\
Diiodomethane $\left(\mathrm{CH}_{2} \mathrm{I}_{2}\right)$ & 50.5 & 0.0 & 0.0 \\
\hline
\end{tabular}

\section{4) Hydrophobicity and surface free energy}

The surface physicochemical properties, including hydrophobicity and surface free energy of bacteria were determined through the contact angle measurements using a goniometer (GBX Instruments) and the calculations using the Van Oss (1993) approach.

According to Vogler (1998), a surface is hydrophobic quantitatively if the measurement of $\theta \mathrm{w}$ is greater than $65^{\circ}$, and it is considered quantitatively hydrophilic if $\theta \mathrm{w}$ is less than $65^{\circ}$.

In addition, conferring Van Oss (1993) approach, the degree of hydrophobicity of a given material is expressed as the free energy of interaction between two entities of that material when immersed in water (w): $\Delta$ Giwi. If the interaction between the two entities is stronger than the interaction of each entity with water, the material is considered qualitatively hydrophobic $(\Delta$ Giwi $<0)$; conversely, for a qualitatively hydrophilic material ( $\Delta$ Giwi $>0$ ). $\Delta$ Giwi is calculated through the surface tension components of the interacting entities, according to the following formula:

$$
\begin{gathered}
\Delta \text { Giwi }=-2 \gamma_{\text {iw }}=-2 \gamma \mathrm{i}\left[\left(\left(\gamma_{i}{ }^{\mathrm{LW}}\right)^{1 / 2}-\left(\gamma_{\mathrm{w}}{ }^{\mathrm{LW}}\right)^{1 / 2}\right)^{2}+2\left(\left(\gamma_{i}^{+} \gamma_{\mathrm{i}}^{-}\right)^{1 / 2}+\left(\gamma_{\mathrm{w}}{ }^{+} \gamma_{\mathrm{w}}{ }^{-}\right)^{1 / 2}-\right.\right. \\
\left.\left.\left(\gamma_{i^{+}} \gamma_{\mathrm{w}}{ }^{-}\right)^{1 / 2}-\left(\gamma_{\mathrm{w}}{ }^{+} \gamma_{\mathrm{i}^{-}}\right)^{1 / 2}\right)\right]
\end{gathered}
$$

where $\gamma^{\mathrm{LW}}$ accounts for the Lifshitz-van der Waals component of the surface free energy and $\gamma+$ and $\gamma-$ are the electron acceptor and electron donor parameters, respectively.

The surface tension components of a solid material are obtained by measuring the contact angles of three pure liquids (one apolar and two polar) with wellknown surface tension components (Absolom et al., 1983), followed by the simultaneous resolution of three equations of the following form:

$$
\gamma_{L}(\operatorname{Cos} \theta+1)=2\left[\left(\gamma_{S}{ }^{L W} \gamma_{L}{ }^{L W}\right)^{1 / 2}+\left(\gamma_{S}{ }^{+} \gamma_{L}^{-}\right)^{1 / 2}+\left(\gamma_{S^{-}} \gamma_{L}^{+}\right)^{1 / 2}\right]
$$




\section{5) Adhesion assay}

The adhesion of investigated bacterial strains to the stainless steel surfaces was performed by sedimentation (Yuan et al., 2008). The stainless steel coupons, prepared such as previously mentioned, were immersed in bacterial suspension concentrated at $10^{9} \mathrm{CFU} / \mathrm{ml}$. The coupons were thus brought into contact with the bacterial cell surfaces for 2, 4 and 6 hours at $25^{\circ} \mathrm{C}$. After incubation, the surfaces were rinsed vigorously with sterile distilled water to remove non-adherent bacteria (Herald \& Zottola, 1988; Briandet et al., 1999).

\section{6) Environmental scanning electron microscopy analysis}

After the adhesion of the two isolates on the stainless steels, the specimens were imaged using Environmental Scanning Electronic Microscopy (ESEM) Quanta 200. This device is equipped with tungsten filament (FEI Company).

\section{7) Statistical analysis}

All data were subjected to one-way ANOVA test, performed with the software package statgraphics Centurion XIV. Differences were considered significant at the $p<0.05$ level of probability.

\section{Results}

\section{1) Molecular identification of microorganisms}

The analysis of the obtained sequences of the 16S rRNA gene and the comparison with the Gen-Bank BLASTN database allowed the molecular identification of the two isolates. The results indicated that the amplified sequences of the two bacteria exhibited a $99 \%$ homology percentage to the 16S rRNA gene of Bacillus pumilus and Staphylococcus haemolyticus.

\section{2) Physicochemical properties of bacteria}

The physicochemical properties of bacteria surface presented in Table 2 revealed that both the bacteria have hydrophilic surfaces qualitatively and qualitatively with $\theta \mathrm{w}=55,9^{\circ}, \Delta \mathrm{Giwi}=27,32 \mathrm{MJ} \cdot \mathrm{m}^{-2}$ for Bacillus pumilus and $\theta \mathrm{w}=33,7^{\circ}, \Delta$ Giwi $=29,25 \mathrm{MJ} \cdot \mathrm{m}^{-2}$ for Staphylococcus haemolyticus . The isolate of the Staphylococcus haemolyticus showed the most hydrophilic character.

In addition, the results demonstrated that both studied strains were mainly electron acceptor with high values of $\gamma^{+}=23.5 \mathrm{~mJ} / \mathrm{m}^{2}$ for Bacillus pumilus and $\gamma^{+}=40.4 \mathrm{~mJ} / \mathrm{m}^{2}$ for Staphylococcus haemolyticus , and a small electron donor character $\gamma^{-}=12.7 \mathrm{~mJ} / \mathrm{m}^{2}$ for Bacillus pumilus and $\gamma^{-}=13.2 \mathrm{~mJ} / \mathrm{m}^{2}$ for Staphylococcus haemolyticus. 
Table 2: Results of the hydrophobic properties and electron donor and acceptor character of the surface of isolates

\begin{tabular}{|c|c|c|c|c|c|c|c|}
\hline \multirow{2}{*}{ Isolate } & \multicolumn{3}{|c|}{ Contact angle $\left({ }^{\circ} \pm \mathrm{SD}\right)^{\mathrm{a}}$} & \multicolumn{3}{|c|}{ Surface tension $\left(\mathrm{mJ} \mathrm{m}^{-2}\right)$} & \multirow{2}{*}{$\Delta$ Giwi } \\
\hline & $\theta_{\mathrm{w}}\left({ }^{\circ}\right)$ & $\theta_{\mathrm{F}}\left({ }^{\circ}\right)$ & $\theta \mathrm{D}\left({ }^{\circ}\right)$ & $\gamma_{\text {LW }}$ & $\gamma+$ & $\gamma-$ & \\
\hline \multirow[b]{2}{*}{ Bacillus pumilus } & 55.9 & 46.6 & 97.9 & 9.5 & 23.5 & 12.7 & \multirow[b]{2}{*}{27,32} \\
\hline & $\pm 0,2$ & $\pm 0,1$ & $\pm 0,4$ & $\pm 0,1$ & $\pm 0,2$ & $\pm 0,1$ & \\
\hline Staphylococcus & 33.7 & 29.7 & 91.4 & 12.1 & 40.4 & 13.2 & \multirow{2}{*}{29,25} \\
\hline haemolyticus & $\pm 0,1$ & $\pm 0,3$ & $\pm 0,1$ & $\pm 0,2$ & $\pm 0,3$ & $\pm 0,1$ & \\
\hline
\end{tabular}

${ }^{\mathrm{a}} \pm$ Standard deviations of three measures

\section{3) Physicochemical properties of 304L stainless steel}

The physicochemical characteristics of 304L stainless steel were presented on the Table 3.

Based on these results, stainless steel presented a hydrophobic character qualitatively and quantitatively $\left(\theta \mathrm{w}=63,7 ; \Delta \mathrm{Giwi}=-21,1 \mathrm{MJ} \cdot \mathrm{m}^{-2}\right)$, with a weak character of electron donor and none electron acceptor character.

Table 3: Results of the hydrophobic properties and electron donor and acceptor character of the $304 \mathrm{~L}$ stainless steel surface

\begin{tabular}{|c|c|c|c|c|c|c|c|}
\hline \multirow{2}{*}{ Substrate } & \multicolumn{3}{|c|}{ Contact angle $\left({ }^{\circ} \pm \mathrm{SD}\right)^{\mathrm{a}}$} & \multicolumn{3}{|c|}{ Surface tension $\left(\mathrm{mJ} \mathrm{m}^{-2}\right)$} & \multirow{2}{*}{$\Delta$ Giwi } \\
\hline & $\boldsymbol{\theta}_{\mathrm{w}}\left({ }^{\circ}\right)$ & $\theta_{\mathrm{F}}\left({ }^{\circ}\right)$ & $\theta_{\mathrm{D}}\left({ }^{\circ}\right)$ & $\gamma_{\text {LW }}$ & $\gamma+$ & $\gamma-$ & \\
\hline 304L stainless steel & $\begin{array}{l}63,7 \\
\pm 0,13\end{array}$ & $\begin{array}{l}50,0 \\
\pm 0,06\end{array}$ & $\begin{array}{l}36,1 \\
\pm 0,04\end{array}$ & $\begin{array}{l}41,4 \\
\pm 0,3\end{array}$ & $\begin{array}{l}0,0 \\
\pm 0,02\end{array}$ & $\begin{array}{l}18,7 \\
\pm 0,1\end{array}$ & $-21,1$ \\
\hline
\end{tabular}

${ }^{\mathrm{a}} \pm$ Standard deviations of three measures

\section{4) Adhesion assay of bacteria on 304L stainless steel surface's}

The analysis of the surfaces of the stainless steel coupons by the ESEM shows that both the two isolates are able to adhere to the mentioned surface. The ESEM images (Fig.1) showed the strong capacity of adhesion of both bacteria. The strain of Staphylococcus haemolyticus (Fig.1-E, F and G) has displayed a bigger ability of adhesion than Bacillus pumilus (Fig.1-B, C and D). Both the strains have presented their adhesion ability within two hours' time. In addition, the micrographs displayed that the adhesion concentration increase with time, especially for Staphylococcus haemolyticus strain. 

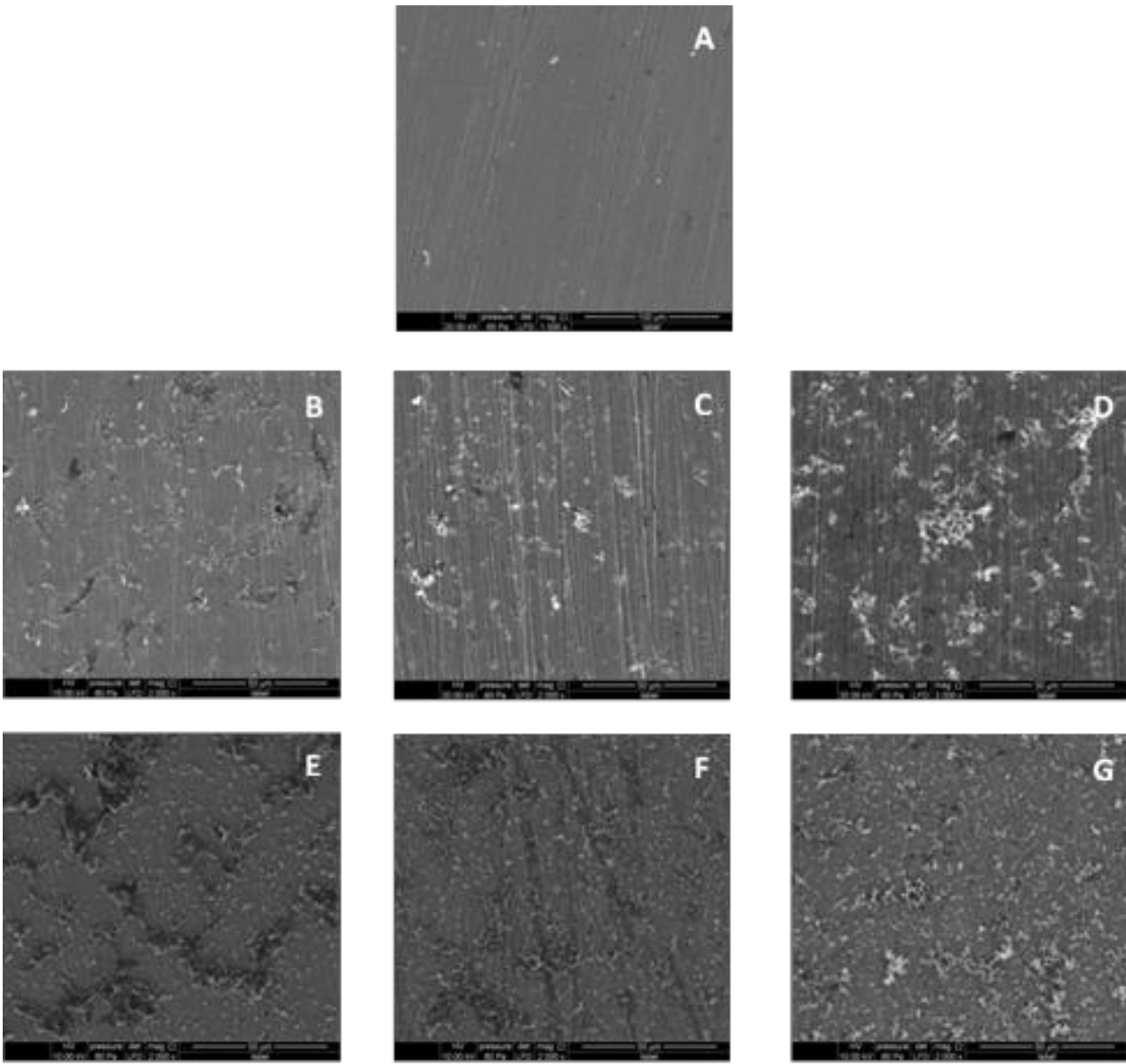

Fig.1. Electron micrographs of bacteria adhesion on 304L stainless steel surface

A: stainless steel surface without adhesion

B: Adhesion of Bacillus pumilus after $2 \mathrm{H}$

E: Adhesion of Staphylococcus haemolyticus after $2 \mathrm{H}$

C: Adhesion of Bacillus pumilus after $4 \mathrm{H}$

F: Adhesion of Staphylococcus haemolyticus after 4H

D: Adhesion of Bacillus pumilus after $6 \mathrm{H}$

G: Adhesion of Staphylococcus haemolyticus after 6H

\section{Discussion}

As generally known, hydrophobic bacteria adhered to a support which has the same character, as well as bacteria and a surface which are hydrophilic. As revealed in the Figure 1 and Tables 2 and 3, there is a contradiction between the theoretical predictions and the adhesion test results. The two isolates whose surface is hydrophilic have the ability to adhere to the surface of stainless steel which is hydrophobic, which indicates that hydrophobicity has no influence on the adhesion of bacteria to the surface of stainless steel, which is shown by El Abed et al. (2010) who reported that the 
hydrophobic character does not influence Aspergillus niger membership and Penicillium expansum on the surface of cedar wood.

In addition, there are a numerous factors that can explain the contrariness between the theoretical predictions and the experimental observations. Bayoudh et al. (2006) reported that the theoretical prediction is limited to the first stages of attachment and does not account for the biological specific interactions. Some authors suggested other explanations and hypotheses that can be involved in the contrariness between theoretical predictions and experimental observations, for example, chemical and morphological heterogeneities of the membrane surfaces also some additional types of interactions including surface roughness and interactions between the membranes and the foulants (Molina et al., 1999; Grabbe \& Horn, 1993; Yotsumoto \& Yoon, 1993; Truesdail et al., 1998; Ducker et al., 1991).

Furthermore, the physico-chemical characteristics of a bacterial strain, including hydrophobicity and the electron donor / acceptor nature, are related to the composition of bacteria membrane. Boonaert \& Rouxhet (2000) have reported that the hydrophilicity of two bacterial strains Lactobacillus helveticus and Lactococcus lactis is due to the high concentration of oxygen and a low concentration of hydrocarbons. Moreover, Hamadi et al. (2012) showed that the hydrophilicity of the cell surfaces correlates directly with the two functions $(\mathrm{C}(\mathrm{O}, \mathrm{N}))$ and $(\mathrm{OH}, \mathrm{COC})$ which correspond to polysaccharides, and contrariwise with the function $(\mathrm{C}-(\mathrm{C}, \mathrm{H}))$, which corresponds to hydrocarbons (Cuperus et al., 1993). The presence of oxygen and nitrogen to the surface of cells promotes interactions with water molecules (via hydrogen bonds) and therefore reduces its hydrophobicity.

The electrons donor / accept character of a bacterial strain is also related to the composition of the membrane, Hamadi et al. (2012) have shown that the phosphate group has the major role in defining the nature of electron donor (base), while the electron acceptor character is related to the low concentration of the amine group and the high concentration of polysaccharides.

Moreover, several works have reported that the hydrophobicity cannot always explain the results of microbial adhesion to the support (PrattTerpstra et al., 1988; Sjollema et al., 1990) and the acid-base interactions play a very important role in this phenomenon (Hamadi \& Latrache, 2008; Henriques et al., 2004). Also, Van Oss (1993) reported that the acidbase interactions are 10-100 times more important compared to other interactions.

In addition, the stainless steel has revealed a hydrophobic character qualitatively and quantitatively with a weak character of electron donor and none electron acceptor character. This result correlates with the number of studies on the same type of stainless steel (304L), Rubio et al. (2002) reported 
that the result of the measurement of the contact angle of 304L stainless steel surface showed that it is hydrophobic $(\theta \mathrm{w}=78.9 \pm 3.2)$, with a low electron donor character $(6.4 \mathrm{~mJ} \mathrm{~m}-2)$ and almost no electron acceptor character $(0.3$ $\mathrm{mJ} \mathrm{m}-2)$.

\section{Conclusion}

This work attempt to investigate Bacillus pumilus and Staphylococcus haemolyticus adhesion capacity on 304L stainless steel in atmospheric simulated medium. The adhesion test showed that both bacteria were able to adhere even though those results were not theoretically predicted. These results will be valuable for a better understanding of microbial adhesion that triggered biocorrorion.

\section{References:}

1. Absolom DR, Lamberti FV, Policova Z, Zingg W, Van Oss CJ, Neumann AW. (1983). Surface thermodynamics of bacterial adhesion. Appl. Environ. Microbiol. AEM 46:90-97.

2. Agarry, S. E., Oghenejoboh, K. M., Aworanti, O. A., \& Arinkoola, A. O. (2018). Biocorrosion inhibition of mild steel in crude oil-water environment using extracts of Musa paradisiaca peels, Moringa oleifera leaves, and Carica papaya peels as biocidal-green inhibitors: kinetics and adsorption studies. CEC, 1-27.

3. Barkai H, Sadiki M, El Abed S, Mostakim, M. , Mohammed, I. H., Saad, I. K. (2015). Comparison of the evolution of physico-chemical properties due to the single and combined adhesion of two species of the Penicillium genus on cedar wood. JMES; 6:749-755.

4. Bayoudh, S., Othmane, A., Bettaieb, F., Bakhrouf, A., Ouada, H. B., \& Ponsonnet, L. (2006). Quantification of the adhesion free energy between bacteria and hydrophobic and hydrophilic substrata. Mater. Sci. Eng. C, 26(2-3), 300-305.

5. Boonaert, C. J. P., \& Rouxhet, P. G. (2000). Surface of Lactic Acid Bacteria: Relationships between Chemical Composition and Physicochemical Properties. J Appl Environ Microbiol, 66(6), 25482554.

6. Briandet, R., Leriche, V., Carpentier, B., \& Bellon-Fontaine, M.-N. (1999). Effects of the Growth Procedure on the Surface Hydrophobicity of Listeria monocytogenes Cells and Their Adhesion to Stainless Steel. . J Food Prot, 62(9), 994-998.

7. Chen, X., Weibel, J. A., \& Garimella, S. V. (2015). Exploiting Microscale Roughness on Hierarchical Superhydrophobic Copper Surfaces for Enhanced Dropwise Condensation. Advanced Materials Interfaces, 2(3), 1400480. 
8. Cuperus, P. L., van der Mei, H. C., Reid, G., Bruce, A. W., Khoury, A. H., Rouxhet, P. G., \& Busscher, H. J. (1993). Physicochemical Surface Characteristics of Urogenital and Poultry Lactobacilli. J. Colloid Interface Sci., 156(2), 319-324.

9. De Romero MF, Urdaneta S, Barrientos M, Romero G. (2004). Correlation between desulfovibrio sessile growth and OCP, hydrogen permeation, corrosion products and morphological attack on iron, Paper No. 04576, CORROSION 2004, NCAE International.

10. Ducker, W. A., Senden, T. J., \& Pashley, R. M. (1991). Direct measurement of colloidal forces using an atomic force microscope. Nature, 353(6341), 239-241.

11. El Abed, S., Hamadi, F., Latrache, H., Iraqui, H. M., \& Ibnsouda, K. S. (2010). Adhesion of Aspergillus niger and Penicillium expansumspores on Fez cedar wood substrata. Ann Microbiol, 60(3), 377-382.

12. Grabbe, A., \& Horn, R. G. (1993). Double-Layer and Hydration Forces Measured between Silica Sheets Subjected to Various Surface Treatments. J. Colloid Interface Sci., 157(2), 375-383.

13. Hamadi, F., \& Latrache, H. (2008). Comparison of contact angle measurement and microbial adhesion to solvents for assaying electron donor-electron acceptor (acid-base) properties of bacterial surface. Colloids Surf. B: Biointerfaces, 65(1), 134-139.

14. Hamadi, F., Latrache, H., Zahir, H., El Abed, S., ELoulai, M., Ibnsouda Koraichi, S. (2012). The relation between the surface chemical composition of Escherichia coli and thier electron donor/electron acceptor (Acid-base) properties. Res J Microbiol, 7, 32-40.

15. Hassan, B., Soumya, E. A., Moulay, S., Mohammed, I. H., \& Saad, I. K. (2014). A Study on the Impact of the Adhesion of Penicillium expansumon the Physicochemical Surface Properties of Cedar Wood. J. ADHESION, 92(5), 341-348.

16. Henriques, M., Azeredo, J., \& Oliveira, R. (2004). Adhesion of Candida albicans and Candida dubliniensis to acrylic and hydroxyapatite. Colloids Surf. B: Biointerfaces, 33(3-4), 235-241.

17. Herald, P. J., \& Zottola, E. A. (1988). Scanning Electron Microscopic Examination of Yersinia enterocolitica Attached to Stainless Steel at Selected Temperatures and pH values. J Food Prot, 51(6), 445-448.

18. Javaherdashti, R. (2016). Microbiologically Influenced Corrosion (MIC). Microbiologically Influenced Corrosion, Springer-Verlag London 29-79. ISBN 978-1-84800-074-2.

19. Katsikogianni M, Missirlis YF. (2004). Concise Review of Mechanisms of Bacterial Adhesion to Biomaterials and Techniques 
used in Estimating Bacteria - Material Interactions. eCM. Vol. 8. (Pages 37-57).

20. Molina-Bolívar, J. A., Galisteo-González, F., \& Hidalgo-Alvarez, R. (1999). The role played by hydration forces in the stability of proteincoated particles: non-classical DLVO behaviour. Colloids Surf B Biointerfaces, 14(1-4), 3-17.

21. Mostakim, M., El abed, S., Iraqui, M., Benbrahim, K. F., Houari, A., Gounni, A. S., \& Ibnsouda, S. K. (2011). Biocontrol potential of a Bacillus subtilis strain against Bactrocera oleae. Ann Microbiol, 62(1), 211-216.

22. Narenkumar, J., Elumalai, P., Subashchandrabose, S., Megharaj, M., Balagurunathan, R., Murugan, K., \& Rajasekar, A. (2019). Role of 2mercaptopyridine on control of microbial influenced corrosion of copper CW024A metal in cooling water system. Chemosphere. DOI:10.1016/j.chemosphere.2019.01.193.

23. Pratt-Terpstra, I. H., Weerkamp, A. H., \& Busscher, H. J. (1988). On a relation between interfacial free energy-dependent and noninterfacial free energy-dependent adherence of oral streptococci to solid substrata. Curr. Microbiol, 16(6), 311-313.

24. Queiroz, G. A. de, Andrade, J. S., Malta, T. B. S., Vinhas, G., \& Lima, M. A. G. de A. (2018). Biofilm Formation and Corrosion on Carbon Steel API 5LX60 in Clayey Soil. MR, 21(3). DOI: 10.1590/19805373-mr-2017-0338.

25. Rasheed, P. A., Jabbar, K. A., Rasool, K., Pandey, R. P., Sliem, M. H., Helal, M., Samara. A, Abdullah. A.M, Mahmoud, K. A. (2018). Controlling the Biocorrosion of Sulfate-Reducing Bacteria (SRB) on Carbon Steel using ZnO/Chitosan Nanocomposite as an EcoFriendly Biocide. Cor Sci. DOI:10.1016/j.corsci.2018.12.028.

26. Rocca, E., Rapin, C., \& Mirambet, F. (2004). Inhibition treatment of the corrosion of lead artefacts in atmospheric conditions and by acetic acid vapour: use of sodium decanoate. Cor Sci, 46(3), 653-665.

27. Rubio, C., Costa, D., Bellon-Fontaine, M. ., Relkin, P., Pradier, C. ., \& Marcus, P. (2002). Characterization of bovine serum albumin adsorption on chromium and AISI 304 stainless steel, consequences for the Pseudomonas fragi K1 adhesion. Colloids Surf. B: Biointerfaces, 24(3-4), 193-205.

28. Sadiki, M., Elabed, S., Barkai, H., Balouiri, M., Nasri, A., \& Koraichi, S. I. (2017). The modification of cedar wood surface properties for the prevention of fungal adhesion. IJAA, 75, 40-46.

29. Sjollema, J., Van Der Mei, H. C., Uyen, H. M. W., \& Busscher, H. J. (1990). The influence of collector and bacterial cell surface properties 
on the deposition of oral streptococci in a parallel plate flow cell. J. Adhesion Sci. Technol, 4(1), 765-777.

30. Truesdail, S. ., Lukasik, J., Farrah, S. ., Shah, D. ., \& Dickinson, R. (1998). Analysis of Bacterial Deposition on Metal (Hydr)oxideCoated Sand Filter Media. J. Colloid Interface Sci, 203(2), 369-378.

31. Van Oss, C. J. (1993). Acid-base interfacial interactions in aqueous media. Colloids Surf. A, 78, 1-49.

32. Videla, H. A. (2002). Prevention and control of biocorrosion. INT BIODETER BIODEGR, 49(4), 259-270.

33. Videla, H. A., \& Herrera, L. K(2004). Chapter 7 Biocorrosion. Petroleum Biotechnology - Developments and Perspectives, 193-218. Elsevier. ISBN 0444516999.

34. Vogler, E. A. (1998). Structure and reactivity of water at biomaterial surfaces. Adv. Colloid Interface Sci., 74(1-3), 69-117.

35. Yotsumoto, H., \& Yoon, R.-H. (1993). Application of Extended DLVO Theory. J. Colloid Interface Sci, 157(2), 434-441.

36. Yuan, S. J., Pehkonen, S. O., Ting, Y. P., Kang, E. T., \& Neoh, K. G. (2008). Corrosion Behavior of Type 304 Stainless Steel in a Simulated Seawater-Based Medium in the Presence and Absence of Aerobic Pseudomonas NCIMB 2021 Bacteria. Ind. Eng. Chem. Res., 47(9), 3008-3020. 